\title{
PNEUMATOLOGICZNY WYMIAR KOŚCIOŁA I TEOLOGII WEDŁUG JOHNA D. ZIZIOULASA
}

\section{PNEUMATOLOGICAL DIMENSION OF THE CHURCH AND THEOLOGY ACCORDING TO JOHN D. ZIZIOULAS}

John D. Zizioulas' publications do not include a special study of his Pneumatology, but his lectures on dogmatic theology contain a lot of material on the pneumatological vision of the Church. The foundation of the Church's faith is the revealed and communicated truth of God, the preservation of which is a special task of the Holy Spirit. He is always active in community and creates communion, and all His gifts are for unity. The truth is revealed and secured only in the communion of the Holy Spirit in the Church. Zizioulas writes that it is the Holy Spirit who constitutes the true "essence of the Church". Hence, Orthodox theologians often conceive of the Church as "an everlasting Pentecost event". Thanks to the Son, we can get to know God, while the Holy Spirit reveals that God is communion. The great mistake of generations of dogmatists was to separate Christology from the science of God - and therefore from pneumatology. Salvation is realized in the Church, which is after all God's people united in Christ and in the Holy Spirit. The Holy Spirit is the Spirit of communion, and it is no exaggeration to identify the Kingdom of God with Himself. The Eucharist is communion and participation in the Blood of Christ, which is "full of the Holy Spirit" and shares in Christ - and at the same time "in the communion of the Holy Spirit". In the face of christomonistic or charismatic constraints, Zizioulas reminds us that Christ does not build the Church without the Holy Spirit, and He does not come to the Church only when he is completely formed. The institution of the Church was established at a specific point in history, but is constantly constituted and renewed by the Holy Spirit. The Church receives 
everything from God through Christ in the Holy Spirit, but it is necessary to receive His gifts in the event of communion - and it is in the Holy Spirit that everything what happens is an event of communion.

Key words: Holy Spirit, truth, theology, ecclesiology, communion.

John D. Zizioulas jest jednym z najbardziej znanych prawosławnych ekumenistów greckich, którego teksty „cechuje niecodzienna wręcz klarowność i metodologiczna poprawność” ${ }^{1}$. Uznanie w całym świecie przyniosły mu książki poświęcone relacjom pomiędzy antropologią i eklezjologią - w szczególności osobie ludzkiej, wolności, prawdzie, komunii i ontologii inności². Zostały wydane w języku angielskim, co przyczyniło się też do szerokiej recepcji jego myśli w świecie 3 . Pełna uznania recepcja nie oznacza jednak braku krytyki ze strony własnego środowiska kościelnego ${ }^{4}$. Jednym z powodów jest pewnie przekonanie Zizioulasa, iż trzeba interpretować przekazaną tradycję teologiczną w taki sposób, żeby odpowiadała na potrzeby ludzkie w naszym czasie - szczególnie w kontekście kultury zachodniej. Oznacza to konieczność wierności wobec historii, ale także raczej interpretacji niż prostego powtarzania doktryny chrześcijańskiej5. Mimo nieprzychylnego nieco nastawienia do niego części

1 R. Małecki, Kościót jako wspólnota. Dogmatyczno-ekumeniczne studium eklezjologii Johna Zizioulasa, Lublin 2000, s. 13.

2 J.D. Zizioulas, Being as Communion. Studies in Personhood and the Church, New York 1985; tenże, Communion and Otherness. Further Studies in Personhood and the Church, London - New York 2006; tenże, Lectures in Christian Dogmatics, London - New York 2009; tenże, The Eucharistic Communion and the World, London - New York 2011.

3 Zob. J. Wong Yee Kheong, John Zizioulas' Ecclesiology of 'The One and the Many', Otago 2019, https://ourarchive.otago.ac.nz/bitstream/handle/10523/9239/WongJeffrey2019PhD. pdf?sequence $=1 \&$ isAllowed $=y$ [08.11.2020], s. I-VII.

4 Por. K. Leśniewski, „Kim jest cztowiek, że o nim pamiętasz...?” Podstawowe idee antropologii prawosławnej, Lublin 2015, s. 31n.

5 Zizioulas powołuje się we wstępie do swoich wykładów na Gieorgija Florowskiego: "In the inspired words of the late Father Georges Florovsky, the message of the Fathers must be phrased today 'in such a way as to secure an ecumenical, a truly universal appeal. This obviously cannot be achieved by any servile repetition of the Patristic letter ... servility is alien both to the Bible and to the Fathers ... The East must face and meet the challenges of the West, and the West perhaps has to pay more attention to the legacy of the East... Theological tradition must be reintegrated, not simply summed up and accumulated'. This monopatristic synthesis, as Florovsky termed it, is the task to which Orthodox theology is called today" (Preface, [w:] tenże, Lectures in Christian Dogmatics, s. X). Cytowany tekst Florowskiego pochodzi z The lagacy and the task of Orthodox theology, zamieszczonego w „Anglican Theological Review” 31 (1949), s. 65-71. Według Zizioulasa „rozwój nauk przyrodniczych stanowi błogosławieństwo dla współczesnej teologii. Jest on wyzwaniem, 
własnego środowiska kościelnego na podkreślenie zasługuje jego otwartość ekumeniczna i systematyczna teologia zdecydowanie przesycona myślą komunijną ${ }^{6}$ W opublikowanych wykładach z dogmatyki chrześcijańskiej już na początku pierwszego rozdziału pisze o teologii wyrastającej z czci oddawanej Bogu i komunii kościelnej? Teologia nie jest bowiem po prostu owocem zwykłego doświadczenia religijnego, moralnego czy psychologicznego, lecz całościowego doświadczenia komunii w Duchu Świętym8.

\section{Prawda w komunii Ducha Świętego}

Teologia zaczyna się od czci oddawanej Bogu i doświadczenia komunii z Nim. Zadaniem Kościoła jest osądzanie, jak należy rozumieć nauczanie przekazane w Piśmie Świętym i doktrynie Kościoła oraz jak rozwijać je w każdorazowej sytuacji ${ }^{9}$. Nauczanie chrześcijańskie musi być zgodne z historycznym Objawieniem Chrystusa i Jego przyszłym nadejściem w chwale, a zachowanie tej jedności oraz transformacja przeszłości i przyszłości jest specjalnym zadaniem Ducha Świętego. Wypełnianie tego zadania nie polega ani na interwencji mechanicznej czy magicznej, ani na udoskonalaniu ducha ludzkiego, lecz na prowadzeniu do komunii skupionej na wspólnocie, która ma wymiary horyzontalne i wertykalne. Na tym polega właśnie eklezjalne działanie Ducha Świętego, którego owocem jest zawsze komunia Chrystusa ${ }^{10}$.

zmuszającym teologów do twórczego przeorientowania teologii, zwłaszcza antropologii. Nasz autor postuluje więc ponowne odczytanie antropologii Ojców w świetle dorobku współczesnej nauki. Nie chodzi tutaj o swego rodzaju „antropologiczny konkordyzm”, ale o twórczą reinterpretację patrystycznej antropologii z punktu widzenia człowieka końca XX wieku, wzbogaconego niepomiernie o wiedzę o sobie samym i otaczającym go świecie. [...] W swoim antropologicznym zwrocie do greckich Ojców Kościoła i ich egzystencjalnej lekturze Zizioulas zbliża się tutaj do innego greckiego teologa i filozofa Christosa Yannarasa" (R. Małecki, Kościót jako wspólnota. Dogmatyczno-ekumeniczne studium eklezjologii Johna Zizioulasa, s. 37).

6 Por. R. Małecki, Kościót jako wspólnota..., s. 14-17.

7 Por. J.D. Zizioulas, Lectures in Christian Dogmatics, s. 1.

8 Por. tamże, s. $1-5$.

9 Por. tamże, s. $7 \mathrm{n}$.

10 Por. tamże, s. 10; M. Jagodziński, Communional Aspects of the Doctrine of the Holy Spirit According to John D. Zizioulas, „Teologia w Polsce” 14 (2020) nr 1, s. 33-35; R. Małecki, Kościót jako „communio” w relacyjnej eklezjologii Johna D. Zizioulasa, „Studia Włocławskie” 1 (1998), s. 87: „Kościół jest Ciałem Chrystusa, ale jednocześnie przestrzenią Ducha Świętego. To On, Trzecia Osoba Trójcy Świętej, wzbudzając Chrystusa z martwych czyni z Niego osobę eschatyczną, istniejącą już nieodłącznie ze swoim Ciałem, tj. z Kościołem. W ten sposób, tak jak w początkach tajemnicy Wcielenia Duch wprowadzał Jezusa w historię, tak teraz przez Zmartwychwstanie uwalnia Go niejako z jej ram". 
Musimy zdecydowanie uwolnić się od rozpowszechnionego myślenia, że Duch Święty działa w nas jako w odizolowanych osobach, a potem pozostawia nas w takim samym stanie. To w Starym Testamencie Duch był dawany poszczególnym osobom, prorokom i królom, a nie całemu ludowi. W Nowym Testamencie Mesjasz udziela Ducha Świętego całemu ludowi Bożemu (św. Łukasz nawiązuje w opisie Pięćdziesiątnicy - $\mathrm{Dz} 2,17 \mathrm{n}$ - do proroctwa Joela). Ducha Świętego wraz z Jego charyzmatami i darami posiadają więc wszyscy ochrzczeni, a nie tylko niektórzy. Święty Paweł odrzucał w Pierwszym Liście do Koryntian manifestowanie jakiegokolwiek elitaryzmu twierdząc, że nawet gdyby ktoś miał wiarę tak wielką, iż mógłby „góry przenosić”, a miłości by nie miał, byłby niczym ${ }^{11}$. Powiew Ducha Świętego zawsze przynosi ze sobą koniec indywidualizmu i elitaryzmu oraz tworzy komunię. To On zwołuje wspólnotę i wszystkie Jego dary służą jedności wspólnoty Kościoła. Objawienie prawdy zawsze przynosi coś z komunii Chrystusa. Nauczanie chrześcijańskie zawsze wskazuje na tę komunię i uczy, że komunią jest też trwanie w prawdzie ${ }^{12}$.

Prawda objawienia Bożego jest empiryczną rzeczywistością w ciele Kościoła, który raduje się relacją Syna do Ojca. Ta relacja - konstytuująca wspólnotę i tworząca ciało Kościoła - jest aktualizowna przez Ducha objawiającego Boga w świecie ${ }^{13}$. Prawda jest objawiona i zabezpieczona - i w tym sensie nieomylna - tylko wtedy, gdy podporządkowujemy się komunii Ducha Świętego i jesteśmy włączeni w ciało Kościoła ${ }^{14}$. Boga nie ma bowiem poza komunią Ducha i tworzoną przez Niego miłością ${ }^{15}$.

Choć Duch Święty działa w ramach widzialnie uchwytnej historii i sam pozostając „ukrytym” nigdy nie objawia w obrębie ekonomii Zbawienia własnego oblicza - pozostaje zawsze niejako „w cieniu" - doprowadzając do spełnienia Boży plan Zbawienia. Stąd teologowie prawosławni mówią o „kenozie Ducha Świętego” ${ }^{16}$ czy o „samozasłonięciu” Jego własnej twarzy. Według

$11 \quad$ Por. J.D. Zizioulas, Lectures in Christian Dogmatics, s. 11.

12 Por. tamże, s. 12.

13 Por. tamże, s. 13.

14 Por. M. Jagodziński, Komunijna mistyka eklezjalna wedtug Johna D. Zizioulasa, „Roczniki Teologiczne” 67 (2020) z. 7, s. 13.

15 Por. tamże, s. 16. "We have said that knowledge of God is offered to us within a loving relationship of the Father and die Son in which God is identified and known eternally, quite apart from us. We identify God in Christ as we become part of this existing relationship. This knowledge is the function of this relationship of love so God is known within the community constituted by these relationships. The Holy Spirit sustains the relationships of love that make up the community of Christ" (tamże, s. 34).

16 Zob. P. Evdokimov, Duch Święty w tradycji prawosławnej, tłum. M. Żurowska, Poznań 2012, s. 17-20. 
Bobrinskoy’a Duch Święty jest „Ikonografem Kościoła”. Zizioulas mówi wręcz, że to Duch Święty stanowi prawdziwą „esencję Kościoła”. To dlatego właśnie tradycja prawosławna łączy powstanie Kościoła z wydarzeniem Pięćdziesiątnicy. Zesłanie Ducha Świętego jest bowiem zgromadzeniem na powrót rozproszonego ludu Bożego we wspólnocie Kościoła ${ }^{17}$. Dzięki temu wielu prawosławnych teologów pojmowało Kościół jako „wydarzenie ustawicznej Pięćdziesiątnicy”18.

\section{Duch Pocieszyciel w szukaniu prawdy o Bogu}

Chrystus objawił prawdę o Bogu i odszedł do Ojca, ale pozostawił Kościół, który oczekuje na powtórne Jego przyjście. Nie pozostawił jednak Kościoła samemu sobie: „Ja zaś będę prosił Ojca, a innego Pocieszyciela da wam, aby z wami był na zawsze - Ducha Prawdy, którego świat przyjąć nie może, ponieważ Go nie widzi ani nie zna. Ale wy Go znacie, ponieważ u was przebywa i w was będzie. Nie zostawię was sierotami: Przyjdę do was" (J 14, 16-18). Gdy Chrystus zasiadł po prawicy Ojca, Ojciec zesłał innego „Pomocnika” - Ducha prawdy. Nowe doświadczenie relacji z Bogiem zaczęło się właśnie wraz z przybyciem tej trzeciej Osoby - Ducha Świętego. Pierwsi uczniowie musieli znaleźć dla Niego miejsce w swoim doświadczeniu Boga i w ten sposób rozpoczęła istnienie nowa wspólnota transcendująca stworzone ograniczenia, której świat nie znał przed Jego przyjściem ${ }^{19}$.

Dla teologii zajmującej się przede wszystkim prawdą o Bogu ogromne znaczenie miało zastosowanie w niej pojęcia osoby ${ }^{20}$. Zizioulas nieustannie podkreśla, że nie natura jest w Bogu początkiem Osób Boskich. To osoba Ojca jest „przyczyną” istnienia Boga jako Trójcy - jakkolwiek „Ojciec” nie ma znaczenia poza relacją z Synem i Duchem, która implikuje Komunię niedopuszczającą bycia w izolacji. Komunia osobowa należy więc do samego centrum bytowania

17 Por. R. Małecki, Kościót jako wspólnota..., s. 84n.

18 Por. W. Hryniewicz, Duch Święty - Mistagog Bożego Królestwa, [w:] P. Evdokimov, Duch Święty w tradycji prawosławnej, s. 12-14.

19 Por.J.D.Zizioulas, Lectures in Christian Dogmatics, s. 44n. „Duch Święty nie jest jedynie siłą ożywiającą i animującą Kościół. Jego zbawcze działanie stoi u samych podstaw zaistnienia Kościoła. To On jest przecież Duchem komunii, gromadzącym w jedno rozproszone dzieci Boże. W obecnym czasie przypomina i uobecnia w Kościele całe misterium naszego Pana. Będąc eschatycznym darem ukazuje mu jednocześnie jego ostateczną celowość i swego rodzaju «narzędziowość» w relacji do całej stworzonej rzeczywistości” (R. Małecki, Kościót jako wspólnota..., s. 77).

20 Por. J.D. Zizioulas, Lectures in Christian Dogmatics, s. 50n. 
Boga, który jest miłością ${ }^{21} \mathrm{i}$ bez tego bycia komunią nieprzekazywalna specyfika poszczególnych Osób Trójcy Świętej nie mogłaby istnieć22.

Obraz Ojca w Synu jest ostateczną treścią bytu komunikowanego w komunii i przez nią ${ }^{23}$. Zizioulas wskazuje przy tym na św. Augustyna, który przypisywał Osobom Trójcy poszczególne atrybuty ich działania w ekonomii Zbawienia. Według niego, Boga możemy poznawać przez Syna, ale atrybut komunii należy do Ducha Świętego, który objawia, że Bóg jest Komunią 24. Greccy Ojcowie Kościoła, zaznacza Zizioulas, unikali jednak przypisywania atrybutów osobowych poszczególnym Osobom Trójcy ${ }^{25}$.

\section{Zbawienie w Duchu Świętym}

Wcielenie Chrystusa można zrozumieć tylko w odniesieniu do Ojca i Ducha. Zizioulas podkreśla, że wielkim błędem wcześniejszych generacji dogmatyków było oddzielanie chrystologii od nauki o Duchu Świętym. W miłości Ojciec zadecydował o Wcieleniu, Syn zgodził się z wolą Ojca i zstąpił do ludzi, a Duch Święty podtrzymywał ten plan wspierając Syna w cierpieniu. Duch Święty trwał przy Chrystusie we wszystkich momentach potwierdzających Jego wolność

$21 \quad$ "Christianity did not invent the notion that God is love. [...] the phrase 'God is love' means that God is constituted by these personal relationships. God is communion; love is fundamental to his being, not an addition to it. [...] Love, or communion with other persons, is stronger than death and is the source of our existence. That 'God is love' means that God is the communion of this Holy Trinity. God the Father would lose his identity and being if he did not have the Son, and the same applies to the Son and to the Spirit. If we took away the communion of the Trinity to make God a unit, God would not be communion and therefore would not be love" (tamże, s, 53). "God is love in his very being. It is not however himself that he loves, so this is not self-love. The Father loves the Son and the Spirit, die Son loves the Father and the Spirit, the Spirit loves the Father and the Son: it is another person that each loves. It is the person, not the nature or essence, who loves, and the one he loves is also a person. Because divine love is a matter of personal communion this love is free: each person loved is free to respond to this love with love" (tamże, s. 53n).

22 Por. tamże, s. 58. "Thus each person of the Holy Trinity is unique and irreplaceable precisely because each i.s. in an unbroken relationship with the other persons. If this communion is severed, that person is lost. Communion, therefore, is a condition for the person, indeed communion creates singularity" (tamże).

23 Por. J.D. Zizioulas, Being as Communion..., s. 101, 104; M. Jagodziński, Communional Aspects of the Doctrine of the Holy Spirit..., s. 36n.

24 Por. J.D. Zizioulas, Lectures in Christian Dogmatics, s. 70; M. Jagodziński, Communional Aspects of the Doctrine of the Holy Spirit..., s. 37n.

25 Por. J.D. Zizioulas, Lectures in Christian Dogmatics, s. 71. 
i nieustannie Go wspomagał ${ }^{26}$. Tam, gdzie jest Duch Święty, pokonywane są zawężenia natury i następuje wyzwalanie ze wszystkiego, co ogranicza. Ponieważ Duch jest zawsze z Chrystusem podczas całej Jego egzystencji, w najbardziej charakterystyczny dla siebie sposób obecny jest z Nim w momentach decydujących o realizacji Bożego planu Zbawienia świata ${ }^{27}$. Zbawienie dokonuje się dzięki prawdzie i zależy w ostateczności od utożsamienia prawdy z komunią ${ }^{28}$. Zbawienie realizuje się w Kościele, który jest zebranym przez Boga ludem Bożym, reprezentującym cały świat zjednoczony w Chrystusie i w Duchu Świętym $^{29}$. Zizioulas pisze, że Wcielenie Chrystusa nie byłoby ostateczną realizacją Kościoła bez następującej po nim Pięćdziesiątnicy i naszego osobowego wcielenia w Kościół. Kiedy św. Paweł omawia Ciało Chrystusa w 1 Kor 12, pisze, że jest ono ludem Bożym, ponieważ Duch Święty zwołuje jego członków do bycia razem ${ }^{30}$. Dlatego nie można uprawiać eklezjologii w izolacji od teologii

26 Por. tamże, s. 148. „W Zmartwychwstaniu dokonuje się [...] prawdziwa «de-indywidualizacja» Chrystusa. [...] Duch Święty jako «moc» i «dawca życia» czyni Chrystusa bytem relacyjnym par excellence. Tak jak w momencie Wcielenia Duch Święty «wprowadził» Chrystusa w obręb historii, tak teraz w Zmartwychwstaniu mocą tego samego Ducha zostaje On uwolniony z ram historii, by istnieć jako «wydarzenie relacyjne», obejmujące w sobie całą ludzkość. To wszystko dokonuje się «w Duchu», jako że wraz z Duchem Świętym «ostatnie dni» (por. Dz 2, 17) wkraczają w obręb historii. Ten nowy sposób Chrystusowego istnienia otwiera zjednoczoną z nim rzeczywistość stworzoną ku prawdziwemu życiu, które na powrót odzyskuje swój relacyjny i komunijny charakter" (R. Małecki, Kościót jako wspólnota..., s. 67).

27 Por. J.D. Zizioulas, Lectures in Christian Dogmatics, s. 106-108, 132n. "The role of the Holy Spirit, though all-important, has been so underestimated that we could even say that it has been suppressed. The incarnation requires the whole doctrine of God. Trinity begins with the goodwill of the Father, continues with the Son taking on the fate of fallen creation and ends with Christ gathering us and all creation up by the Holy Spirit. The Holy Spirit always acts through Christ, because Christ is the point where all mankind and all creation are gathered up and brought into living communion with God on whom there are no confines. The incarnation is therefore not just about Christ's receiving the Holy Spirit, but also about Christ giving the Holy Spirit to all mankind..." (tamże, s. 108). Por. J.D. Zizioulas, Being as Communion..., s. 101.

29 "Zizioulas maintains that central to the Eucharist together with Christ, is the Person and work of the Holy Spirit, who comes to dwell in the Church (Eph. 2.22) through the Eucharistic epiclesis and, who brings the eschaton into her life and mission (Acts 2.1721).42 This image of the Church as the Temple of the Holy Spirit (1 Cor. 6.19, 2 Cor. 6.16; Eph. 2.21-22) is founded upon the New Testament and according to Zizioulas, "implies that the Church is not simply a unity, but a unity in diversity and personal freedom." In short, Zizioulas argues that the Holy Spirit constitutes the Church while Christ institutes her. The difference between these two prefixes: in- and con- "can be enormous ecclesiologically," according to Zizioulas" (J. Wong Yee Kheong, John Zizioulas' Ecclesiology of 'The One and the Many', s. VIII). 
(nauki o Bogu ${ }^{31}$. Duch Święty jest Duchem komunii, mocy i życia, który burzy bariery rozdzielające wszelkie byty oraz umożliwia komunię ${ }^{32}$.

Powołując się na jeden z hymnów na dzień Pięćdziesiątnicy, Zizioulas pisze, że Duch Święty utrzymuje w jedności całą instytucję Kościoła i dodaje, że nie jest żadną przesadą utożsamianie Królestwa Bożego z Duchem Świętym ${ }^{33}$. Kiedy modlimy się o nadejście tego Królestwa, prosimy o Ducha Świętego. Łączenie Go z instytucją Kościoła oznacza, że sama ta „instytucja” i jej ramy, wewnątrz których staje się ona rzeczywistością - czyli zgromadzenie eucharystyczne wywodzą swoje znaczenie od Królestwa Bożego. Zizioulas wspomina Mikołaja Kabazylasa, który pisał, że w Eucharystii powtórzenie słów Pana dokonuje się w „formie narracji”, ale przemiana darów w Ciało i Krew Chrystusa należy do Ducha Świętego. To On gromadzi „na jednym miejscu” eschatologiczną wspólnotę, w ramach której dokonuje się transformacja eucharystyczna ${ }^{34}$. Eucharystia jest Komunią i udziałem we Krwi Chrystusa, która jest „pełna Ducha Świętego". Mamy więc w niej udział w Chrystusie - ale w tym samym czasie także „w komunii Ducha Świętego” (zwrot pochodzi z Liturgii św. Bazylego). Duch Święty zstępuje nie tylko na przedstawione dary, lecz także „na nas”. W ten sposób „realna obecność” Chrystusa jest poszerzana na Głowę i Ciało w jedności Ducha Świętego, a Eucharystia jako komunia Ducha Świętego staje się „komunią świętych” - świętych rzeczy i świętych ludzij

Teologia Wschodu bardzo mocno podkreśla eschatologiczny wymiar Kościoła, który wyznaje, że Duch Święty wnosi do historii przyszłośććc ${ }^{36}$. Światowe królestwa opierają się na przeciwieństwach i wspólzawodnictwie, ale Duch

$31 \quad$ Por. tamże, s. 132.

32 Por. tamże, s. 136. "The Holy Spirit enables the communion of the created with the uncreated so this body can enable the communion of ever being with every other. [...] the Holy Spirit enables us to exceed the limits of our creaturely being and enter that communion with God which is God's love. Beings must have boundaries so that they can be acknowledged as distinct, but they must surmount these boundaries in order to come into communion with one another and so live as a society. Creatures must be able to distinguish themselves from God who is the source of their communion. The Holy Spirit enables both this demarcation and its transcendence and so makes all community possible" (tamże, s. 139). Por. R. Małecki, Kościót jako wspólnota..., s. 86.

33 Por. P. Evdokimov, Prawostawie, tłum. J. Klinger, Warszawa 2003, s. 156.

34 Por. J.D. Zizioulas, The Eucharistic Communion and the World, s. 73n.

35 Por. tamże, s. 75 n.

$36 \quad$ "Zizioulas emphasizes, "The Holy Spirit is associated, among other things, with koinonia (2 Cor. 13.13) and the entrance of the last days into history (Acts 2.17-18), that is, eschatology." There is a strong eschatological dimension to the presence and the activity of the Holy Spirit who is the spirit of liberty and who blows wherever He wills" (J. Wong Yee Kheong, John Zizioulas' Ecclesiology of 'the one and the many', s. 106). 
Święty wprowadza wszędzie pokój Chrystusa. Pięćdziesiątnica jest spełnieniem wszystkich czasów. I chociaż wielu chrześcijan uważa, że zesłany Duch Święty oświeca osobiście jednostki, to jest to tylko prawda częściowa. Duch Święty uwalnia bowiem ludzi z różnorodnych ograniczeń związanych z historią jednostek, narodów czy grup społecznych. On wciąga ich w o wiele większe wymiary przyszłości, w których są wolni do bycia dla siebie wzajemnie - i to bez żadnych ograniczeń. Życie udzielane przez Ducha Świętego nie jest pokawałkowane, otrzymujemy je w całości, dzięki czemu wiemy, że wszyscy chrześcijanie - z przeszłości, teraźniejszości czy przyszłości - są obecni dla nas w komunii nieograniczonej czasem czy przestrzenią ${ }^{37}$.

\section{Teologia a pneumatologia}

Zizioulas podkreśla, że gdy chrześcijański Zachód próbował jakoś rozwijać pneumatologię, nie bywała ona włączana w eklezjologię. Kościół był raczej traktowany jak rzeczywistość przede wszystkim historyczna, do której Duch Święty wnosi element raczej dodatkowy i prawie kosmetyczny. Dla takiej teologii Kościół był raczej zbudowany z materiału historii, jego wspólnota przybierała formę przeszłości, a Duchowi Świętemu przypadało jedynie zadanie ożywiania jej. Prawda jest jednak taka, że Duch Święty buduje Kościół wraz z Synem i nie przybywa do Kościoła dopiero wtedy, gdy ten jest już w pełni ukończony. Jeżeli Kościół jest niepodzielnym dziełem Trójjedynego Boga, w które zaangażowane są wszystkie osoby Trójcy Świętej, nie możemy także pozwolić na przemycanie do myślenia teologicznego jakiegokolwiek śladu myślenia o rywalizacji pomiędzy Boskimi Osobami ${ }^{38}$.

Wschód odpowiadał na zachodni chrystomonizm nadmiernym akcentowaniem Ducha Świętego ${ }^{39}$. Żeby zademonstrować różnicę w stosunku do Zachodu, Aleksiej Chomiakow głosił, że Kościół jest komunią Ducha Świętego - pomijając całkowicie jego podstawy chrystologiczne. Uczył, że Prawosławie musi patrzeć na Kościół jako na komunię Ducha Świętego, a nie jako na Ciało historycznego Chrystusa. Wprowadzało to oczywiście natychmiast przeciwieństwo między Synem a Duchem i niedopuszczalne podziały w Bogu. Trzeba ze smutkiem stwierdzić, że taki podział często wystarczał jako podstawa do twierdzenia, iż Duch Święty nie ma nic wspólnego z tradycyjną instytucją Kościoła a Ewangelia nie może być ograniczana przez ramy instytucjonalne. Widać to wyraźnie w kontraście zachodzącym pomiędzy rzekomą wolnością

37 Por. J.D. Zizioulas, Lectures in Christian Dogmatics, s. 154n; R. Małecki, Kościót jako wspólnota..., s. 111.

38 Por. J.D. Zizioulas, Lectures in Christian Dogmatics, s. 149.

39 Por. R. Małecki, Kościót jako wspólnota..., s. 80-n. 
charyzmatycznych wspólnot eklezjalnych a Kościołami z „instytucjonalnymi” posługami apostolskimi i biskupimi, będącym katastrofalnym skutkiem przesadnego akcentowania pneumatologii kosztem chrystologii ${ }^{40}$.

Zizioulas pisze, że za każdym razem, gdy jakiś lider charyzmatyczny tworzy nową i bardziej „duchową” wspólnotę, dzieli Ciało Chrystusa na duchowe i nie-duchowe albo na charyzmatyczne i nie-charyzmatyczne oraz daje znać, iż właściwie nie potrzebuje połowy tego Ciała. Takie rozróżnianie między „duchowym” a „instytucjonalnym” Kościołem oznacza jednak zapomnienie o „zwykłych” chrześcijanach - jeśli można ich tak nazwać. Czy nie są oni wszyscy członkami Ciała Chrystusa? Czy Duch Święty opuścił ich? Charyzmatyczni przywódcy, którzy stawiają się poza porządkiem i urzędem w Kościele ${ }^{41}$, uważają, że chrzest nie dokonuje udzielenia Ducha Świętego ${ }^{42}$. Ale jak może nie udzielać

$40 \quad$ Por. J.D. Zizioulas, Lectures in Christian Dogmatics, s. 149, 151. Zizioulas powoluje się w kwestii syntezy chrystologii i pneumatologii na dorobek N. Nissiotisa i B. Bobrinskoy'a, którzy „zgodnie podkreślają, iż zbawcze dzieło Chrystusa i Ducha Świętego przynależą do siebie wzajemnie. Są jakby dwiema stronami jednego i tego samego misterium Zbawienia, które swój początek zawdzięcza inicjatywie Ojca realizowanej przez Chrystusa w Duchu Świętym. Nie jest ważne to, że tajemnica Chrystusa poprzedza w chronologicznym porządku misterium Pięćdziesiątnicy. Historyczny porządek zbawczych wydarzeń nie może bowiem przesłaniać głębi całego misterium Kościoła. Nauka o Kościele nie powinna więc kierować się tylko zwykłą logiką następstwa historycznych wydarzeń. Tajemnica Kościoła powstaje z jednego, integralnie rozumianego, chrystologiczno-pneumatologicznego wydarzenia. Chronologiczny priorytet chrystologii przed pneumatologią równoważy fakt, iż sam Chrystus od początku swej ziemskiej działalności ukazuje się jako osoba «napełniona Duchem Świętym» (por. Łk 1, 15; 4, 1.18). W Ewangelii św. Jana posłanie Ducha Świętego jest częścią wydarzenia chrystologicznego (por. J 7, 39; 20, 22). To Duch Święty jest tym, który objawia Chrystusa, Chrystus zaś tym, który posyła Ducha od Ojca. Jak zauważa Bobrinskoy, to prawo wzajemności istniejące pomiędzy Duchem i Synem staje się podstawową zasadą trynitarnej ekonomii Zbawienia" (R. Małecki, Kościót jako wspólnota..., s. 83).

41 Na temat Ducha Świętego jako twórcy porządku w Kościele zob. R. Małecki, Kościót jako wspólnota..., s. 136-139.

42 „Grecki teolog zauważa, że wszystkie nowotestamentalne konotacje chrzcielne mówią o chrzcie dokonującym się «W» (eis) Chrystusa «w» (en) Duchu Świętym. To trudne do oddania w języku polskim rozróżnienie gramatyczne wskazuje na samą istotę sakramentu chrztu. Jest nią inkorporacja «w» Chrystusa dokonująca się poprzez (czy też «w mocy») Ducha Świętego. Odtąd chrześcijanin ma szansę urzeczywistniać swoje istnienie w nowy, komunijny sposób na wzór Chrystusa. Poprzez sakrament chrztu także sam nowo ochrzczony zostaje niejako poddany procesowi «de-indywidualizacji». Przyswaja sobie nową, kościelną hipostazę. Zizioulas stwierdza: dopiero teraz człowiek ma szansę na istnienie prawdziwie osobowe, wolne od konieczności, jakie niesie ze sobą poprzez fakt biologicznych narodzin. Chrzest, jako narodziny «w» Duchu, różni się bowiem od biologicznych narodzin" (tamże, s. 69). 
Go, skoro to On chrzci i udziela wszystkich sakramentów? ${ }^{33}$ Protestanci nie są zbyt zainteresowani instytucją Kościoła, a niektórzy nawet wątpią, czy Chrystus chciał jego istnienia. Duch Święty jest przez nich traktowany jako inspirator, który asystuje indywidualnie każdej osobie - i ogólnie całej wspólnocie - właściwie tylko po to, żeby mogła przyjąć słowo Boga ${ }^{44}$.

W obliczu ewentualnych zawężeń chrystomonistycznych czy charyzmatycznych Zizioulas przypomina, że Chrystus nie buduje Kościoła bez Ducha Świętego, a Duch Święty nie przybywa do Kościoła dopiero wtedy, gdy on już istnieje w pełni ${ }^{45}$. Instytucja Kościoła powstała bowiem raz na zawsze w określonym punkcie historii, ale jest nieustannie konstytuowana i odnawiana przez Ducha Świętego ${ }^{46}$. To On gromadzi chrześcijan wokół Chrystusa, nadając mu podstawowe struktury i urzędy przez chrzest, bierzmowanie ${ }^{47}$ i święcenia.

$43 \quad$ Por. J.D. Zizioulas, Lectures in Christian Dogmatics, s. 149n. "Some generations later George Florovsky very justifiably corrected Khomiakov, bin he did so equally without nuance, by insisting that ecclesiology should be understood merely as a sub-section of Christology. The emphasis returned to the history of Jesus Christ, again conceived as confined by history as much as any other individual. Others like Lossky, Nissiotcs and Bobtinskoy responded to Florovsky by placing all the emphasis back on the Spirit again. However, ecclesiology is not a matter of either Christ or the Spirit, but of all the persons of the Trinity in indivisible unity. When we emphasise the Spirit we must be clear that that we are speaking of the realisation of that recapitulation of all things in The Son. The choice is not between a christological ecclesiology on one hand and a pneumatological ecclesiology on the other, but between a christo-monist ecclesiology and a fully trinitarian ecclesiology in which all the persons of God are at work. The proper basis of ecclesiology is the trinitarian doctrine of God. The role of the Holy Spirit should never lead tis into an ecclesiology not founded in Christ; ecclesiology cannot be Spirit-centred because the Church is the recapitulation of everything in Christ" (tamże, s. 150). Por. rozważania Zizioulasa na temat jedności chrztu, bierzmowania i Eucharystii w The Eucharistic Communion and the World, s. 114-116.

44 Por. J.D. Zizioulas, Lectures in Christian Dogmatics, s. 156.

45 Por. tenże, Being as Communion..., s. 111.

$46 \quad$ Por. tenże, Lectures in Christian Dogmatics, s. 157: "The Church is that congregation which is created by the Spirit as a portrayal of eschatological events, every time, in every place and whenever the divine Eucharist is performed. The Church is farmed by the freelywilled gathering of Christians. [...] The structure, the institution of the Church is not something that is imposed by someone for we ourselves compose and constitute it The Holy Spirit makes us all its founding members as he gathers us together as the Church, so the Church does not come into existence without us". Por. tenże, The Pneumatological Dimension of the Church, „Communio. Internationl Catholic Review” 2 (1972), s. 133-147.

47 Wspólna Tradycja Kościoła zawsze uważała bierzmowanie za sakrament Ducha Świętego, a jego obrzędy widocznie wyrażały i uobecniały Jego działania, jakkolwiek to chrzest rozumiany był od początku jako nowa Pięćdziesiątnica. Udzielana podczas bierzmowania moc Ducha Świętego staje się osobistą mocą uzdalniającą chrześcijanina do świadczenia o Zmartwychwstaniu Chrystusa. Por. R. Małecki, Kościól jako wspólnota..., s. 71n. 
Święcenia biskupie są przecież manifestacją założenia Kościoła przez Ducha Świętego i odnowieniem Pięćdziesiątnicy. Duch Święty wraz z Synem nieustannie rekonstytuuje Kościół, który w ten sposób otrzymuje też od eschatonu swoją ciągłość ${ }^{48}$.

Zizioulas prezentuje przy tym typowo wschodnią ocenę nauczania kościelnego. Pisze, że gdy biskupi gromadzą się na synodzie, są częścią większej całości konstytuowanej przez Ducha Świętego, a autorytet nauczania kościelnego wyrasta ostatecznie z Ducha poruszającego wszystkie członki Kościoła. Konkretna decyzja czy interpretacja może okazać się błędna, tak jak błędna może okazać się jakaś historyczna opinia czy interpretacja uczonych. Tylko cały Kościół dysponuje odpowiednio długim istnieniem, które - poprzez wszystkie sobory i dzięki czci oddawanej Bogu - daje dostęp do pełnej prawdy Boga ${ }^{49}$.

\section{Recepcja w Duchu Świętym}

Pojęcie recepcji teologicznej jest głęboko zakorzenione $\mathrm{w}$ historii i bycie Kościoła, który narodził się, rósł i rozwijał się dzięki niej. Kościół najpierw otrzymuje wszystko od Boga - przez Chrystusa - w Duchu Świętym ${ }^{50}$. Ojciec Wacław Hryniewicz pisał, że kto wierzy, otrzymuje od Chrystusa nowe życie i pozwala się przeniknąć przez Ducha Świętego Jego prawdą. „W Kościele dokonuje się ustawiczna wymiana poglądów, ich krytyczna recepcja lub modyfikacja. Możliwe są także zjawiska braku recepcji. Dotyczy to różnych poziomów życia kościelnego. Najczęściej chodziło o przyjęcie orzeczeń soborowych bądź synodalnych przez inne wspólnoty kościelne. O recepcji można ponadto mówić w odniesieniu do poglądów teologicznych przyjmowanych wzajemnie od siebie

$48 \quad$ Por. J.D. Zizioulas, Lectures in Christian Dogmatics, s. 156. "The Church is always the creation by the Spirit in one place in time of the coming events of the eschaton, The Church is the summation and recapitulation of the world, so it is only through its continued incorporation in the Church that the world survives. The being of the Church is the outcome of the present work of the Holy Spirit, who enacts the labour of Christ, rendering the whole body of Christ alive and present for this specific time and place" (tamże). Szczególne miejsce zajmuje w tej dziedzinie Eucharystia: "The Eucharist is the inaugural event of freedom and the moment in which eschatological reality becomes the actual presence of this assembly brought together by the Holy Spirit. This is the work of the Holy Spirit, which is why the invocation (epiclesis) of the Holy Spirit is fundamental. The gifts that bear the body and blood of Christ bring us into increasing participation in that body. This event of person-to-person relationship takes place in the Spirit, between each of us and Christ. These eschatological events are seen, felt and tasted in the gathering of the Church. This gathering is the event in which the Holy Spirit opens us to life together in freedom" (tamże, s. 161). Por. R. Małecki, Kościót jako wspólnota..., s. 87. 
przez teologów. Obok recepcji poglądów ważną rolę odgrywa również recepcja doświadczeń duchowych. Pod pewnym względem jest ona nawet ważniejsza od recepcji sformułowań i wypowiedzi teologicznych. Do niedawna wszystkie te fakty życia kościelnego nie pobudzały do głębszej refleksji nad ich znaczeniem i rolą w chrześcijaństwie. Obecna sytuacja ekumeniczna skłania w szczególny sposób do podjęcia takiej refleksji i do wyciągnięcia z niej wszystkich możliwych implikacji dla dzieła pojednania i zjednoczenia. Skoro recepcja - ogólnie mówiąc - jest wyrazem wymiany duchowej między osobami oraz całymi społecznościami, nie może pozostać sprawą obojętną dla przyszłości ekumenizmu i jedności Kościoła. Należy uważać ją za rdzenne zjawisko eklezjalne - życiowy proces dokonujący się we wszystkich Kościołach chrześcijańskich" ${ }^{51}$.

Kwestia formy tej recepcji nauczania jest jednak jedną z najtrudniejszych spraw w obecnej sytuacji ekumenicznej. Bóg dał nam Syna w Duchu Świętym, a więc w wydarzeniu komunii, nie zmusza nas jednak do przyjęcia swego daru. Prawda jest autorytatywna, ale nie autorytarna - przychodzi do ludzi w wydarzeniu komunii, która realizuje się przez konkretną wspólnotę Kościoła ${ }^{52}$. Nie każda jednak wspólnota eklezjalna jest Kościołem. Żadna nie może izolować się od całego Kościoła, ponieważ jest on w szczególny sposób ustrukturyzowany przez wydarzenie komunii - a właśnie w Duchu Świętym wszystko dzieje się jako wydarzenie komunii ${ }^{53}$.

\section{Podsumowanie}

Publikacje Johna D. Zizioulasa nie zawierają opracowania jego pneumatologii, ale jest w nich wiele materiału dotyczącego pneumatologicznej wizji Kościoła. Fundamentem wiary Kościoła jest objawiona i przekazywana w nim prawda Boża, której zachowanie jest specjalnym zadaniem Ducha Świętego. On działa zawsze we wspólnocie i tworzy komunię, a wszystkie Jego dary służą jedności. Prawda jest objawiona i zabezpieczona tylko w komunii Ducha Świętego

51 W. Hryniewicz, Hermeneutykaw dialogu. Szkiceteologiczno-ekumeniczne, t. 2, Opole 1998, s. 150.

52 Por. J.D. Zizioulas, Being as Communion..., s. 130n: "Another important contribution of the Holy Spirit to the Christ event is that, because of the involvement of the Holy Spirit in the economy, Christ is not just an individual, not «one» but «many». This «corporate personality» of Christ is impossible to conceive without Pneumatology. It is not insignificant that the Spirit has always, since the time of Paul, been associated with the notion of communion ( $\kappa o v v \omega v i \alpha$ ). Pneumatology contributes to Christology this dimension of communion. And it is because of this function of Pneumatology that it is possible to speak of Christ as having a «body», i. e. to speak of ecclesiology; of the Church as the Body of Christ".

53 Por. tenże, Lectures in Christian Dogmatics, s. 162n. 
w Kościele. Zizioulas pisze, że to Duch Święty stanowi prawdziwą „esencję Kościoła”. Dlatego teologowie prawosławni często pojmują Kościół jako „wydarzenie ustawicznej Pięćdziesiątnicy". Dzięki Synowi możemy poznawać Boga, natomiast Duch Święty objawia, że Bóg jest Komunią. Wielkim błędem całych generacji teologów było oddzielanie chrystologii od nauki o Bogu - a więc i od pneumatologii. Zbawienie realizuje się w Kościele, który jest ludem Bożym zjednoczonym w Chrystusie i w Duchu Świętym. Duch Święty jest Duchem komunii i nie jest żadną przesadą utożsamianie Królestwa Bożego z Nim samym. Eucharystia jest Komunią i udziałem we Krwi Chrystusa, jest „pełna Ducha Świętego” oraz daje udział w Chrystusie - i równocześnie „w komunii Ducha Świętego". Wobec pojawiających się zawężeń chrystomonistycznych czy charyzmatycznych Zizioulas przypomina, że Chrystus nie buduje Kościoła bez Ducha Świętego, a On nie przybywa do Kościoła dopiero wtedy, gdy jego budowa jest już ukończona. Instytucja Kościoła powstała w określonym punkcie historii, ale jest nieustannie konstytuowana i odnawiana przez Ducha Świętego. Kościół otrzymuje wszystko od Boga przez Chrystusa w Duchu Świętym, konieczna jest jednak recepcja Jego darów, która także dokonuje się w wydarzeniu komunii, a przecież to w Duchu Świętym wszystko dzieje się jako wydarzenie komunii.

Słowa kluczowe: Duch Święty, prawda, teologia, eklezjologia, komunia.

\section{Bibliografia:}

1. Evdokimov P., Duch Święty w tradycji prawostawnej, tłum. M. Żurowska, Poznań 2012.

2. Evdokimov P., Prawosławie, tłum. J. Klinger, Warszawa 2003.

3. Florovsky G., The lagacy and the task of Orthodox theology, „Anglican Theological Review" 31 (1949), s. 65-71.

4. Hryniewicz W., Duch Święty - Mistagog Bożego Królestwa, [w:] P. Evdokimov, Duch Święty w tradycji prawosławnej, tłum. M. Zurowska, Poznań 2012, s. 7-25.

5. Hryniewicz W., Hermeneutyka w dialogu. Szkice teologiczno-ekumeniczne, t. 2, Opole 1998.

6. Jagodziński M., Communional Aspects of the Doctrine of the Holy Spirit according to John D. Zizioulas, „Teologia w Polsce” 14 (2020) nr 1, s. 31-45.

7. Jagodziński M., Komunijna mistyka eklezjalna wedlug Johna D. Zizioulasa, „Roczniki Teologiczne" 67 (2020) z. 7, s. 5-18.

8. Leśniewski K., „Kim jest człowiek, że o nim pamiętasz...?” Podstawowe idee antropologii prawostawnej, Lublin 2015.

9. Małecki R., Kościót jako wspólnota. Dogmatyczno-ekumeniczne studium eklezjologii Johna Zizioulasa, Lublin 2000.

10. Zizioulas J.D., Being as Communion. Studies in Personhood and the Church, New York 1985. 
11. Zizioulas J.D., Communion and Otherness. Further Studies in Personhood and the Church, London - New York 2006.

12. Zizioulas J.D., Lectures in Christian Dogmatics, London - New York 2009.

13. Zizioulas J.D., Preface, [w:] tenże, Lectures in Christian Dogmatics, London - New York 2009, s. IXn.

14. Zizioulas J.D., The Eucharistic Communion and the World, London - New York 2011. 